\title{
Which way out of poverty? The Human Capital versus Human Capabilities approaches $^{1}$
}

\author{
Andrés A. Chavez E. \\ Universidad Internacional del Ecuador (UIDE), Pichincha, Ecuador. \\ Autor para correspondencia: Andres2007eco@hotmail.com, Aac2184@tc.columbia.edu \\ Fecha de recepción: 16 de febrero de 2015 - Fecha de aceptación: 21 de marzo de 2015
}

\begin{abstract}
RESUMEN
La pobreza es un problema mundial que afecta a personas de diferentes maneras. El propósito de este artículo es explorar dos teorías principales que abordan la pobreza y la posibilidad de su superación, que son los enfoques de capital humano y de capacidades humanas. El enfoque del capital humano se centra exclusivamente en la faceta económica de la pobreza; en esta perspectiva, la pobreza se define como la falta de dinero y puede abordarse mediante el aumento de los ingresos financieros de las personas que viven en la pobreza. El enfoque de las capacidades humanas ve la pobreza como un problema multidimensional que va más allá de la economía para áreas como la salud, la educación y la libertad. Este enfoque se orienta hacia el cambio social y ayudar a las personas en situación de pobreza para descubrir y desarrollar su potencial. El autor considera que las capacidades humanas abarcan con mayor precisión el alcance de la pobreza y las personas afectadas por el mismo, aunque debido a su amplia gama ha sido difícil diseñar e implementar políticas eficaces que aborden todas las facetas de la pobreza.
\end{abstract}

Palabras clave: Educación, pobreza, desarrollo, capital humano, capacidades.

\begin{abstract}
Poverty is a global issue that affects people in different ways. The purpose of this article is to explore the two main theories that address poverty and the potential for overcoming it, which are the human capital and human capabilities approaches. The human capital approach focuses exclusively on the economic facet of poverty; in this perspective, poverty is defined as a lack of money and can be addressed by increasing the financial income of persons living in poverty. The human capabilities approach views poverty as a multidimensional problem that extends beyond economics to areas such as health, education, and freedom. This approach is geared towards social change and helping people in poverty to discover and fulfill their potential. The author finds that the human capabilities approach more accurately encompasses the range of poverty and the individuals affected by it, although its broad range has made it difficult to design and implement effective policies that address all the facets of poverty.
\end{abstract}

Keywords: Education, poverty, development, human Capital, capabilities.

\section{INTRODUCTION}

The word poverty can bring a variety of images to a person's mind. These might include a homeless person holding a sign outside of Wal-Mart, a large family sharing a one-room apartment in a dangerous neighborhood, or a television advertisement asking for money to help starving children in

\footnotetext{
${ }^{1}$ Written as a Master degree's student at Columbia University.
} 
Africa. Although the majority of people see poverty around them on a daily basis in one way or another, there is still no universal understanding and agreement of exactly what constitutes poverty.

Different ways of viewing poverty have led to contrasting theories regarding the best way to eradicate it. Among these theories are the human capital approach and human capabilities approach. The purpose of this paper is to discuss how each of these theories defines poverty, explore their approach to contributing to worldwide development, and analyzes how education factors into the policies that they propose.

\section{HUMAN CAPITAL APPROACH}

Authors motivated by the human capital approach generally believe that "the difference between prosperity and poverty for a country depends on how fast it grows [economically] over the long term" (Barro, 2002: 9). They therefore value education to the degree that it contributes to the economic advancement of those who receive it. Education is seen as an investment designed to produce returns in the form of higher earnings. As one theorist explains, while it is true that "any capability produced by human investment becomes a part of the human agent and hence cannot be sold, it is nevertheless 'in touch with the marketplace' by affecting the wages and salaries the human agent can earn." The resulting increase in earning is the yield on the investment (Schultz, 1971: 36). Smith (2009: 166), one of the founders of this approach, essentially likens education's role in development to the sharpening of a tool in a factory. He states that the education that leads to "improved dexterity of a workman may be considered in the same light as a machine or instrument of trade which facilitates and abridges labor, and which, though it costs a certain expense, repays that expense with a profit".

Research methods within the human capital approach involve assessing the economic situations of regions being studied, particularly their growth over time. This is most often tracked using a nation's GDP and observing whether that number has risen or fallen, and by how much, in recent years. Another tool that these theorists use is the number of people living in poverty. The World Bank, which subscribes to the human capital approach, uses a simple standard to determine this; the organization counts all people who live off of two dollars a day or less as being in poverty, and those who live off of $\$ 1.25$ or less as being in extreme poverty (World Bank, 2010). Therefore, one main goal of human capital theorists is to increase individual and nationwide earnings so that fewer people will fall below the line of poverty. Schultz believes that many development efforts have failed because of the way in which capital has been distributed to developing countries. He asserts that money and resources given to these countries from outside sources are generally earmarked for "the formation of structures, equipment, and sometimes also into inventories. But it is generally not available for additional investment in man. Consequently, human capabilities do not stay abreast of physical capital, and they become limiting factors in economic growth" (Schultz, 1971: 34). According to this statement, investment in human training and education is important because it allows residents of developing countries to better take advantage of the resources that they do have and thereby yield a greater return.

Simply put, for a proponent of the human capital approach, education is an important aspect of development so long as the amount of money that it takes to provide the education is less than the increase in wage that the education will eventually produce for the student. The success of an education system can therefore be gauged in this approach by observable changes in the GDP of a given country. In an effort to reduce the costs of education, and thereby increase the return on the investment, this approach has led to neoliberal policies such as privatization and decentralization of education. These policies, which decrease government expenditure on education, have resulted in the financial burden of education falling on the families of the students who attend the schools. Many families in poverty are simply unable to afford these fees, and as a result, a significant number of parents are now unable to send their children to school.

Arnove gives the example of Brazil and Nicaragua, where over 70 percent of the population lives in poverty and at least a quarter suffers from extreme destitution. The majority of these families have three or four children, and if they were asked to pay just one dollar per month for each of their 
children to attend school, they would be forced to choose between sending their children to school and having enough money to buy the food, clothes, and medicine that they need to survive (Arnove, 1997). Therefore, the privatization of education and the school fees that accompany it are a major obstacle to the education of the poor.

The aforementioned standards that the World Bank has set for defining poverty and extreme poverty, which are people who live off of two dollars and $\$ 1.25$ per day, respectively, reveal another flaw in the human capital approach. This idea assumed that if the people of an underdeveloped nation could find a way to increase their income by only one dollar per day, they could break the bonds of poverty and join the ranks of the developed nations of the world. The truth is that, although numbers and GDP are important, the statistical focus of neoliberalism often leads people to forget that each number represents a real human being. Whether it's a father struggling to find food for his family, or a child falling behind in school, the numbers reported by GDP merely serve as a reflection of the genuine human struggle that people in poverty are living through each day. It is the people, not the numbers that matter, and "the people are the real wealth of a nation" (UNDP, 1990).

\section{HUMAN CAPABILITIES APPROACH}

The focus of the human capabilities approach is to enable individuals to lead lives they can value and have sufficient choices to make that life for themselves. Theorists motivated by this perspective evaluate policies across three markers, which are their direct influence on people's wellbeing and freedom, the indirect role that they have on influencing economic production, and the way in which they shape social change (Sen, 1997). In this approach, education is viewed as a vital part of an individual's process of becoming who he or she needs to be, as a quality education provides people with options and allows them to shape their future. This approach assumes that educated people will contribute to economic prosperity and improvements in a nation's social structure.

One defining aspect of the human capabilities approach is that it does not view economic prosperity as the primary factor that leads people to more fulfilling lives; rather, "the scope of the capability approach, by contrast, is as wide as human life and social arrangements stretch in reality" (Robeyns, 2006). Advocates of this approach use the Human Development Index (HDI) to measure development, which takes into account life expectancy at birth, mean years of schooling for people age 25 and over and expected years of schooling for children of school entering age, and gross national income per capita (UNDP, 2013). The fact that the number of years that a nation's residents attend school is factored into HDI shows that education is a critical component of the human capabilities approach. Authors that support this perspective maintain that both education and health care have a significant impact on the quality of life that people can choose to lead. They cite numerous examples of positive social changes that can be brought about by improving human capabilities through education, such as reduced fertility in educated women and improved quality of public debates among those who have completed a basic education (UNDP, 2010).

The human capabilities approach views poverty as a multidimensional problem. As proponents of human development argue, "The dimensions of poverty go far beyond inadequate income - to poor health and nutrition, low education and skills, inadequate livelihoods, bad housing conditions, social exclusion and lack of participation" (UNDP, 2010). Additionally, when poor people themselves define poverty, they tend to focus on other dimensions such as dependency, powerlessness, and lack of voice (Geo-JaJa \& Azaiki, 2010). Rather than cite statistics about poverty, human capability authors generally prefer to illustrate examples of what poverty really looks like. One report details the life of Salome, a 30-year-old woman who lives in the slum in Nairobi. She lives with her husband and six daughters, whose ages range from 3 months to 14 . Her husband is only able to work on rare occasions where there are projects to be done in a nearby industry park. They also have no electricity or running water, and the couple's 6-year-old, Merah, has not yet been enrolled in school because the family cannot afford the $\$ 4$ registration fee. Salome worries every day about not being able to feed her children (UNDP, 2010: 93, box 5.3). Narratives such as this one help agencies to focus on the individuals that they are striving to help rather than focusing solely on numbers that have lost their 
meaning.

This doesn't mean that the numbers don't matter to human capability theorists. Sen (1999: 3) explains that development is "a process of expanding the real freedoms that people enjoy". He further clarifies that focusing merely on economic growth is too narrow a view of development, but that "growth of GNP or of individual income can, of course, be very important as a means to expanding the freedoms enjoyed by the members of society" (Sen, 1999: 3). Therefore, the numbers are important, but only inasmuch as they reflect an improvement in the lives of real individuals like Salome.

In order to address the many facets of poverty, the human capability approach calls for a high quality education system that is intrinsic rather than merely instrumental in nature. This type of education "helps students to acquire the knowledge, skills, and values needed to function effectively within their cultural community, nation state and region and in the global community" (Banks, 2008: 129). In order to accomplish this, education cannot discriminate against cultures, languages, or religions, and it should allow students to be heavily involved in their own educations by granting them the opportunity to choose their own goals and their own path towards those goals (Banks, 2008; Rogers, 1980). The intrinsic aspect of education guides students toward discovering their human capabilities. It also prepares students for the many opportunities, responsibilities, and experiences of adult life, such as applying for jobs, participating in judicial systems, seeking ownership of property, taking care of children, dealing with illness, forming relationships, and so on (Best, 2000).

The broad and all-encompassing nature of the human capability approach, however, has made it difficult to implement. Uvin (2007: 601) states that agencies that subscribe to this vision "remain committed to little more than improved discourse". However, the fact that it hasn't led to great sustainable change yet does not mean that it never will. Uvin continues by expressing the following:

"Major change always starts small, and even rhetorical gains sometimes turn out to be the snowballs that set in motion fresh avalanches. In addition, there are organisations and people, in both rich and poor countries, who are courageously rethinking their longheld ideologies and practices in terms of human rights. And there are many more development practitioners, everywhere, who debate questions in a new manner and try to add layers of accountability, transparency, and organization to their own work. Much more can be done with human rights (Uvin, 2007: 604)."

The improved discourse of the human capabilities approach is a start. It is now the responsibility of its supporters to find new ways to approach policies regarding education and development so that the people of underdeveloped nations can be empowered to make the changes that will improve their individual lives, then their societies, and eventually the world.

\section{THE WAY OUT}

In creating and implementing new education policies to improve education, it is vital that the two approaches of human capital and human capabilities be taken into account. Depending on whether education is valued as a commodity that increases economic development or a workshop that produces active and contributing citizens, the policies that arise will be different in nature and lead to distinct results, both inside and outside of schools (Walker, 2012; Lanzi, 2007).

Human capital will inevitably continue to shape education policies due to the international standards, governments, and agencies that promote "the ideal quality education" which is based on literacy, numeracy and essential life skills (UNESCO, 2007). However, it is clear that education cannot be focused on human capital alone. As Heitor \& Horta (2014: 70) explain, "education institutions cannot be expected to foresee the demands of the employment market in advance". Thus, even from an economic standpoint, education should not be confined to the idea of creating a labor force. Rather, human capital and human capabilities should be pursued in conjunction for the benefit of students and society (Walker, 2010).

It is more complex to include human capabilities in education, partially because the needs of the 
students will differ based on the region they live in, their life circumstances and their goals for the future. However, expending this effort will provide the students with an education that is more relevant and preparatory for their unique futures. In order to tailor the education experience toward each individual student, it will be necessary that the opportunities for student participation in education be increased. Therefore, it is proposed that future education policies should incorporate democracy education and move from lectures and memorization to a student-centered learning process.

Incorporating democracy education and student-centered learning ought to be a goal for future education policies because these approaches focus on guiding students through self-discovery and relevant, active learning rather than disseminating information that may or may not be helpful to them. Democracy education means "that children, parents, communities, employers, political leaders and others have a role in determining the structure, content and process of education" (Tikly \& Barrett, 2011: 5). The involvement of these entities in the education process helps to assure that the education provided is relevant and appropriate for students' situations. Student-centered learning policies require a shift from lecture and memorization; they employ "such techniques as substituting active learning experiences for lectures, assigning open-ended problems and problems requiring critical or creative thinking that cannot be solved by following text examples, involving students in simulations and role plays, and using self-paced and/or cooperative (team-based) learning" (Collins \& O'Brien, 2003). These interactive teaching methods allow students to take responsibility for their own learning and expand their capacities in such a way that would not be possible in a passive learning environment.

Encouraging students to participate in their education is crucial to the development of their capabilities because it helps them to become analytical thinkers and problem solvers (Torney-Purta \& Amadeo, 2004). Armed with the ability to think critically, recognize problems, and search for solutions, students will be prepared to see the injustices and inefficiencies in their societies and work towards overcoming them. As these active citizens exercise their rights, they will make progress towards extending rights to all and ultimately eradicating poverty. An education that simultaneously promotes human capital and human capabilities will necessarily lead to poverty reduction "through forming particular kinds of reasoning graduates, equipping them to participate in the economy but also to contribute more expansively to the social good" (Walker, 2010: 492).

The way out of poverty, therefore, is through the education and development of students who will become the prominent voices of the future. They must be equipped not only with labor skills and facts about society, but with life skills and a desire to improve society as well. These types of students will best be able to develop their abilities and find their voices through an education that places them at the center of their learning and promotes both human capital and human capabilities approaches. They will then be prepared to become agents of change capable of making significant and lasting improvements in their own lives, in their communities, and ultimately in the world.

\section{CONCLUSION}

There are clearly many differences between the human capital and human capabilities approaches. The human capital approach defines poverty in terms of GDP, and specifically how much money a person has to live off of per day. The theory's approach to development involves increasing GDP, and education is used as a tool to increase earnings of workers. The human capabilities approach looks at the people behind the numbers and views poverty as a wide range of rights and freedoms that people lack. Theorists believe that development is a combination of health, education, and living standards, and track development using HDI rather than GDP. Education is viewed as an essential way to help people discover their capabilities so that they can become what they need to be and learn to be empowered to change their societies.

As Uvin (2007) said, there is still much that can be done in the realm of development. There is still an inordinate amount of poverty and suffering in the world. However, as organizations continue to work towards answers, learning to truly listen to those who need help and work with them to create sustainable solutions, development policies will begin to make a real and positive difference. Changes 
need to be made in education policies that reflect not only human capital but human capabilities as well, mainly through democracy education and student-centered learning. If students of the underdeveloped world are empowered through education, they will undoubtedly become citizens capable of enacting change and grow to be great contributors to the community of the world.

\section{REFERENCES}

Arnove, R.F., 1997. Neoliberal education policies in Latin America: Arguments in favor and against. In: Torres, C.A., A.P. Boulder (Eds.), Latin American Education: Comparative Perspectives. CO: Westview, pp. 79-100.

Banks, J., 2008. Diversity, group identity, and citizenship education in a global age. Educ. Res., 37(3), 129-139.

Barro, R.J., 2002. Education as a determinant of economic growth. In: Lazear, E. (Ed). Education in the Twenty-First Century. CA: Stanford, Hoover Institute.

Best, R., 2000. Introduction: Where are we going with SMSC? In: Best, R. (Ed.). Education for Spiritual, Moral, Social, and Cultural Development. London: Continuum, pp. 1-12.

Collins, J.W, N.P. O'Brien (Eds.), 2003. Greenwood Dictionary of Education. CT: Westport, Greenwood.

Geo-JaJa, M.A., S. Azaiki, 2010. Development and education challenges in the Niger Delta. In: Hui Xu, Lou, S., Xiu Lan Wan (Eds.). Studies in African Education. Hangzhou: Zhejiang University Press.

Heitor, M., H. Horta, 2014. Further democratizing Latin America: Broadening access to higher education and promoting science policies focused on the advanced training of human resources. JOTMI, 9(4), 64-82.

Lanzi, D., 2007. Capabilities, human capital and education. J. Socio Econ., 36, 424-435.

Robeyns, I., 2006. Three models of education: Rights, capabilities and human capital. Theory Res. Educ., 4(1), 69-84.

Rogers, C., 1980. A way of being. Boston, MA: Houghton Mifflin Company.

Schultz, T., 1971. Investment in human capital. New York: The Free Press, pp. 24-47.

Sen, A., 1997. Editorial: Human Capital and Human Capability. World Dev., 25(12), 1959-1961.

Sen, A., 1999. Development as freedom. New York: Anchor Books.

Smith, A., 2009. An inquiry into the nature and causes of the wealth of nations. Lawrence, KS: Digireads.com Publishing.

Tikly, L., A.M. Barrett, 2011. Social justice, capabilities and the quality of education in low income countries. Int. J. Educ. Dev., 31, 3-14.

Torney-Purta, J., J.A. Amadeo, 2004. Civic and political participation (pp. 75-90). Generalized trust and trust in institutions (pp. 91-96). Strengthening Democracy in the Americas through Civic Education: An Empirical Analysis Highlighting the Views of Students and Teachers. Washington, DC: Organization of American States.

UNDP (United Nations Development Programme) - Human Development Report Office, 1990. Human Development Reports 1990-2009. New York: Oxford University Press.

UNDP, 2010. Human Development Report 2010, 20th Anniversary Ed., The Real Wealth of Nations: Pathways to Human Development. New York: UNDP.

UNDP, 2013. Indices \& Data | Human Development Index | Human Development Reports (HDR) | United Nations Development Programme (UNDP). Human Development Reports (HDR) - United Nations Development Programme (UNDP). Retrieved from http://hdr.undp.org/en/ statistics/hdi/ in October 2013.

UNESCO, 2007. Education for all. Global monitoring report 2008 - Education for all by 2015: Will 
We Make It? Paris and Oxford: UNESCO and Oxford University Press.

Uvin, P., 2007. From the right to development to the rights-based approach: How "human rights" entered development. Dev. Pract., 17(4), 597-606.

Walker, M., 2010. A human development and capabilities 'prospective analysis' of global higher education policy. J. Educ. Policy, 25(4), 485-501.

Walker, M., 2012. A capital or capabilities education narrative in a world of staggering inequalities? Int. J. Educ. Dev., 32, 384-393.

Word Bank, 2010. Extreme poverty rates continue to fall |Data. Data| The World Bank. Retrieved from http://data.worldbank.org/news/extreme-poverty-rates-continue-to-fall in October 2013. 